\title{
The evolution of viviparity: molecular and genomic data from squamate reptiles advance understanding of live birth in amniotes
}

\author{
James U Van Dyke, Matthew C Brandley and Michael B Thompson \\ School of Biological Sciences, University of Sydney, A08 Heydon-Laurence Building, Sydney, \\ New South Wales 2006, Australia \\ Correspondence should be addressed to J U Van Dyke; Email: james.vandyke@sydney.edu.au
}

\begin{abstract}
Squamate reptiles (lizards and snakes) are an ideal model system for testing hypotheses regarding the evolution of viviparity (live birth) in amniote vertebrates. Viviparity has evolved over 100 times in squamates, resulting in major changes in reproductive physiology. At a minimum, all viviparous squamates exhibit placentae formed by the appositions of maternal and embryonic tissues, which are homologous in origin with the tissues that form the placenta in therian mammals. These placentae facilitate adhesion of the conceptus to the uterus as well as exchange of oxygen, carbon dioxide, water, sodium, and calcium. However, most viviparous squamates continue to rely on yolk for nearly all of their organic nutrition. In contrast, some species, which rely on the placenta for at least a portion of organic nutrition, exhibit complex placental specializations associated with the transport of amino acids and fatty acids. Some viviparous squamates also exhibit reduced immunocompetence during pregnancy, which could be the result of immunosuppression to protect developing embryos. Recent molecular studies using both candidate-gene and next-generation sequencing approaches have suggested that at least some of the genes and gene families underlying these phenomena play similar roles in the uterus and placenta of viviparous mammals and squamates. Therefore, studies of the evolution of viviparity in squamates should inform hypotheses of the evolution of viviparity in all amniotes, including mammals.

Reproduction (2014) 147 R15-R26
\end{abstract}

\section{Introduction}

Reproduction is perhaps the single most important biological function as it is the means by which organisms transmit genes to the next generation. Consequently, modifications of reproductive mode will directly impact fitness and are subject to intense natural selection pressure. Transitions in reproductive mode, between oviparity (egg laying) and viviparity (live birth), require dramatic changes to reproductive morphology and physiology, and are among the most fundamental transitions in vertebrate evolution.

Although viviparity has evolved independently in multiple lineages of vertebrates (Anderson et al. 1972, Frick 1998, Farley 1999), chondrichthyan fish (Wourms 1977), actinopterygian fish (Wourms 1981), mammals, and squamate reptiles (e.g. lizards and snakes; Blackburn 1982), the majority of the morphological, physiological, and evolutionary studies of viviparous animals has focused on mammals. While mammals represent an excellent model for understanding the evolution of placental complexity, they are a poor model to study the transition from oviparity to viviparity, because it likely occurred only once in the ancestor to therian mammals (Lillegraven 1979). Moreover, the transition to mammalian viviparity occurred 191-124 million years ago (the estimated time period between the maximum age of crown Mammalia and minimum age of crown Theria; dos Reis et al. 2012). Therefore, it is unlikely that extant mammals retain identifiable ancestral morphological or genetic signatures of the early stages of this transition because they have been modified over 100 million years of evolution.

On the other hand, the transition to viviparity has occurred independently over 100 times in squamates (Blackburn 1985, 1992, 2000b, 2006). Compared with other taxa, oviparous squamates may even be considered 'preadapted' for viviparity because most species retain eggs for at least the first third of gestation (Blackburn 2006, Blackburn \& Stewart 2011). Within Squamata, viviparity has evolved recently in a number of clades, including at least three lizard species that possess both oviparous and viviparous populations (Zootoca (Lacerta) vivipara (Heulin 1990), Lerista bougainvillii (Heulin 1990, Smith \& Shine 1997, Qualls \& Shine 1998), and Saiphos equalis (Smith \& Shine 1997)). These three species thus represent particularly excellent 
models for studying the general mechanisms by which the transition to viviparity evolved in amniote vertebrates.

Squamates are amniote vertebrates and thus possess the same extraembryonic membranes as mammals, including the amnion, allantois, chorion, and yolk sac (Blackburn 1992, 2000b, 2006). As in viviparous mammals, these membranes interact with adjacent uterine tissues to develop placentae responsible for adhesion to the uterus, respiratory gas exchange, water transport, and nutrient transport. As a result, all livebearing reptiles, even if they rely primarily on yolk for embryonic nutrition (i.e. lecithotrophy), are truly viviparous, rather than ovoviviparous (Blackburn 2000a). Because placentae are formed from homologous tissues in both mammals and squamates, we can directly compare placental structures not only across the squamate phylogeny but also amongst all amniotes. In other words, mechanisms of squamate viviparity may help us to understand the transition to viviparity in amniotes in general, including the transition in early therian mammals. Finally, advances in molecular techniques now allow detailed analysis of gene expression in 'non-model' organisms (e.g. Brandley et al. (2012)). Perhaps the greatest advance has been next-generation transcriptome sequencing, which provides the snapshots of nearly all the genes expressed in a tissue and allows direct comparisons of molecular function amongst squamate lineages and between squamates and mammals.

Here, we review the proximate changes necessary for the transition from oviparity to viviparity in squamates. Specifically, we discuss the development of mechanisms for embryonic implantation and placentation, exchange of respiratory gases, water transport, nutrient transport, and regulation of the maternal immune system. We highlight recent discoveries of molecular and genetic mechanisms involved in the transition because they provide the best opportunity for comparing the viviparous conditions of squamates and mammals.

\section{Implantation and placentation}

By definition, viviparous animals must retain embryos in utero until embryogenesis is complete, which means that viviparity must evolve coincident with mechanisms to keep developing embryos inside the uterus during development. If specialized placental structures transport water, gases, and nutrients between mothers and offspring, then adhesion mechanisms are necessary to keep the uterine and embryonic components of these structures adjacent throughout development. Uterine plasma membrane transformations similar to those that facilitate implantation in the rat, including flattening of the apical plasma membrane of uterine epithelial cells, occur during pregnancy in the skink genera Niveoscincus and Eulamprus (Murphy et al. 2000, Hosie et al.
2003). Throughout pregnancy, uterine tissues opposite the yolk sac of viviparous skinks of the genera Pseudemoia, but not Saiphos, exhibit decreases in desmosome expression (Biazik et al. 2010a). During pregnancy, occludin expression increases in the uterine tissues of Pseudemoia, but not in Saiphos or Eulamprus skinks (Biazik et al. 2007). In addition, claudin 5 expression increases throughout pregnancy in the uterine tissues of Eulamprus, Pseudemoia, and Saiphos (Biazik et al. 2008). Interestingly, decreasing desmosome density reduces adhesion between uterine cells, while increasing density of occludin and claudin- 5 both increase adhesion between uterine cells. Desmosomes, occludin, and claudins are all involved in the modifications of uterine tissues before blastocyst implantation in rats (Nicholson \& Murphy 2005, Preston et al. 2006), so could serve similar purposes in squamates. Alternatively, they could regulate paracellular permeability to the molecules transported between maternal and fetal tissues during pregnancy (Biazik et al. 2010b).

Unlike eutherian mammals, most squamate embryos exhibit both a chorioallantoic placenta on the embryonic pole (Fig. $1 \mathrm{~A}$ and $\mathrm{B}$ ) and some form of yolk-sac placenta on the abembryonic pole (Fig. 1C; Weekes 1935, Hoffman 1970, Guillette et al. 1981, Blackburn 1992, Stewart 1992, 1993). Both placentae are formed via close appositions of uterine and embryonic tissues, and are defined as epitheliochorial in most viviparous reptiles (Blackburn \& Vitt 2002, Adams et al. 2005) because the embryonic tissues do not breach or invade uterine epithelia. In extant mammals, epitheliochorial placentation has likely evolved secondarily from moreinvasive hemochorial or endotheliochorial placentation (Mess \& Carter 2007). The uteri of epitheliochorial mammals exhibit physical barriers to invasion and produce secretions that hinder invasion mechanisms of the embryos, but the embryos themselves are capable of invading other maternal tissues in extra-uterine pregnancies (Samuel \& Perry 1972). In contrast, extra-uterine embryos in the viviparous skink, Pseudemoia entrecasteauxii, which exhibits complex placentation and substantial placentotrophy, are not capable of invading maternal tissues (Griffith et al. 2013b). Thus, epitheliochorial placentation in reptiles is probably not maintained by maternal resistance to uterine invasion, but occurs because reptile embryos lack the ability to invade maternal tissues. Exceptions may occur in skinks of the genera Mabuya and Trachylepis, both of which exhibit invasive placental specializations that may facilitate attachment to uterine tissues. In Mabuya, embryonic cells from the chorioallantois send cytoplasmic projections through the syncytial cells of the uterine epithelium to interact with uterine capillaries (Vieira et al. 2007). In Trachylepis, embryonic epithelial cells from the chorioallantois invade, and ultimately replace, uterine epithelial tissue, and lie in direct contact with the uterine capillaries (Blackburn \& Flemming 2012). 

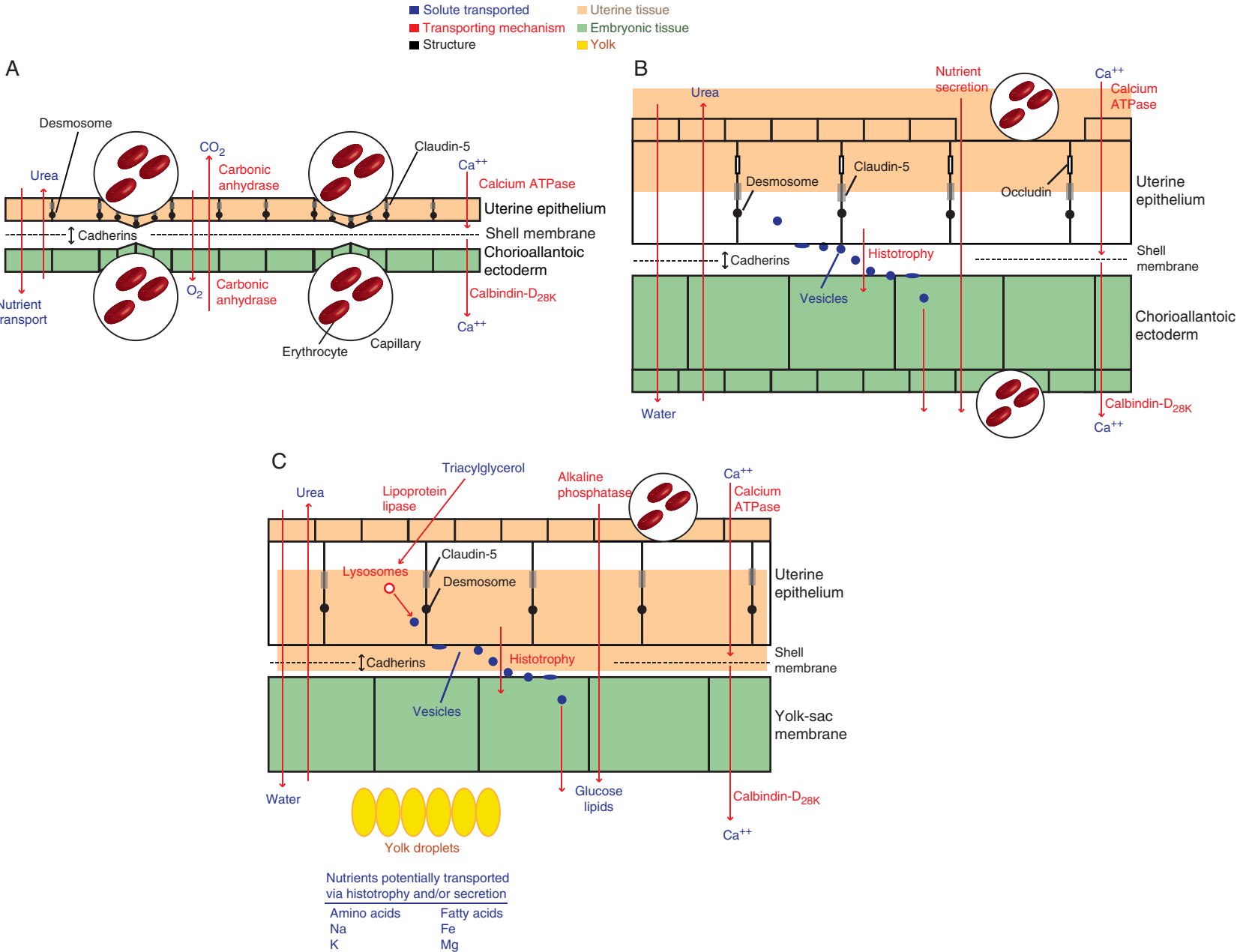

Figure 1 Hypothetical schematic illustration of the placentae in viviparous squamates based on the best available information from multiple species (nearly all scincid lizards). Embryo-maternal communication likely facilitates the regional diversification of placental tissues described in (A, B and C), but the mechanisms underlying communication remain unknown. (A) Chorioallantoic placenta: in species that have a placentome, this illustration represents the paraplacentome region of the chorioallantoic placenta only. Both uterine and embryonic membranes are typically made up of simple squamous cells, and are attenuated near capillaries to facilitate respiratory gas exchange. Nutrient transport may occur in the paraplacentome/chorioallantoic placenta, but only transport of $\mathrm{Na}, \mathrm{K}$, and water has been documented in nonplacentotrophic species, and the mechanisms of transport for most nutrients are unknown in most species. (B) Placentome region of the chorioallantoic placenta, which is found only in viviparous squamates that exhibit a placentome. Uterine and embryonic membranes of the placentome are usually composed of columnar or cuboidal cells. Nutrient transfer might occur in the placentome via histotrophy, secretion, or both. Limited gas exchange may also occur. (C) Yolk-sac placenta. Uterine and embryonic membranes of the yolk-sac placenta are usually composed of columnar or cuboidal cells, and the yolk-sac membrane may only include a single cell layer. Histotrophic nutrient transport may not occur in species that are not placentotrophic. Other mechanisms of nutrient transfer, including alkaline phosphatase, lipoprotein lipase, and lysosomes, have only been studied in Pseudemoia species. In all placentae, desmosomes, claudin-5, and/or occludin may regulate cellular adherence in the uterine epithelium, but have only been investigated in a few species of Scincid lizards. Similarly, cadherins may play a role in adhering embryonic and maternal tissues during implantation, but have only been studied in Niveoscincus species. Genes potentially upregulated in the uterus, but not localized to any particular region, include apolipoproteins, aquaporins, cysteine and serine proteases, cystatins, fatty acid-binding proteins, ion transporters, protease inhibitors, solute carrier proteins, and genes involved in angiogenesis (e.g. VEGFs and EPAS1).

Except in species whose placental tissues exhibit any embryonic invasion of uterine epithelium (i.e. Mabuya and Trachylepis), mechanisms that allow embryonic attachment to uterine tissues remain largely unknown in viviparous reptiles (Murphy \& Thompson 2011). In mammals that exhibit epitheliochorial placentation, embryonic attachment to the uterus is accomplished via interdigitation of embryonic and uterine tissues, as well as proliferation of integrins (Jones et al. 2000,
Burghardt et al. 2009). Cadherins mediate changes in uterine epithelial cells that are necessary before implantation in mammals with hemochorial placentation (Hyland et al. 1998, Dey et al. 2004). Few squamate placentae exhibit interdigitation of maternal and embryonic tissues (Blackburn 1992) and, in the skink genus Niveoscincus, cadherins are a potential mechanism of embryonic attachment rather than integrins (Wu et al. 2011). 
Genes putatively used in the growth and remodelling of the placenta are by far the most highly upregulated genes in the uterus of the skink, Chalcides ocellatus, during pregnancy (Brandley et al. 2012). In mammals, proteases and their inhibitors continuously remodel the placenta by destroying and building new tissue (Salamonsen \& Nie 2002). The cathepsin family of cysteine proteases play a major role in this process in multiple lineages of mammals (Afonso et al. 1997, Divya et al. 2002, Song et al. 2006, 2010, Varanou et al. 2006). Proteases are also some of the most highly expressed genes in the pregnant $C$. ocellatus uterus; cathepsins B, $\mathrm{L}$, and $\mathrm{V}$ mRNAs comprise almost $8 \%$ of all the mRNAs of all genes expressed in the pregnant uterus (Brandley et al. 2012). Moreover, because tissue remodelling is achieved by the reciprocal actions of proteases and their inhibitors (Afonso et al. 1997, Salamonsen \& Nie 2002, Song et al. 2006, 2007, 2010), it is notable that there is also significant upregulation of cysteine and serine protease inhibitors such as cystatins, tissue factor pathway inhibitor 2 (TFPI2), and serine peptidase inhibitor, Kunitz types 1 and 2 (SPINT1 and 2) in the pregnant $C$. ocellatus uterus. It is unclear whether similar genes are used by all viviparous squamates for placental growth and remodelling, or whether the strength of their expression is linked to placental complexity.

Most viviparous squamates are lecithotrophic (i.e. rely on yolk for nutrition) and exhibit simple chorioallantoic (Fig. 1A) and yolk-sac placentae (Fig. 1C) with little morphological specialization (Weekes 1935, Bellairs et al. 1955, Hoffman 1970, Yaron 1977, Guillette et al. 1981, Stewart 1990, 1992, 1993). In contrast, viviparous skinks of the genera Niveoscincus, Pseudemoia, Chalcides, Eumecia, Mabuya, and Trachylepis exhibit complex chorioallantoic placentae and increasing reliance on placentotrophy (Weekes 1935, Blackburn etal. 1984, Ghiara et al. 1987, Blackburn 1992, Flemming \& Branch 2001, Blackburn \& Vitt 2002, Stewart \& Thompson 2004, 2009a, Adams et al. 2005, Blackburn \& Flemming 2012). The chorioallantoic placenta is differentiated into a paraplacentome (Fig. 1A) and a placentome (Fig. 1B) in Pseudemoia, Chalcides, and Mabuya (Blackburn 1993b, Stewart \& Thompson 1996, Blackburn \& Vitt 2002), but not in Niveoscincus, Eumecia, or Trachylepis (Flemming \& Branch 2001, Stewart \& Thompson 2004, Blackburn \& Flemming 2012). The placentome is a region in the dorsal center of the chorioallantoic placenta, which is defined by thickened, occasionally interdigitating uterine and chorioallantoic tissues directly beneath the uterine mesometrium (Weekes 1935, Blackburn et al. 1984, Blackburn 1993b). The paraplacentome surrounds the placentome and exhibits little thickening or interdigitating of uterine and chorioallantoic tissues, but capillaries in both tissues are closely apposed (Fig. 1A; Blackburn 1993b). The uterine component of the chorioallantoic placenta in the lecithotrophic skink Eulamprus quoyii also develops a placentome-like structure late in development, but its function remains unclear (Murphy et al. 2011) and is absent from other Eulamprus skinks (Murphy et al. 2012). Yolk-sac placental structure also varies among viviparous squamates (Stewart \& Blackburn 1988), and varying degrees of specialization occur among species regardless of reliance on placentotrophy (Stewart 1992, Stewart \& Thompson 2004, 2009a, 2009b, Thompson et al. 2006).

\section{Respiratory gas exchange}

Gestating female squamates flux oxygen and carbon dioxide with the environment for developing embryos (Beuchat \& Vleck 1990, Schultz et al. 2008, Van Dyke \& Beaupre 2011), so the uterus must transport respiratory gases to and from developing embryos. Possibly to facilitate the flux of oxygen and carbon dioxide, squamates exhibit progressive thinning of the eggshell the longer eggs are retained before oviposition (Heulin 1990, Qualls 1999, Heulin et al. 2002). The eggshell and shell membrane are thinned via reductions in either the number of shell glands present in the oviduct (Guillette 1993), or a reduction in the size of the shell gland which presumably impedes function (Heulin et al. 2005). Most viviparous species retain a reduced eggshell membrane (Blackburn 1998), but it is lost during gestation in placentotrophic species (Blackburn et al. 1984, Stewart \& Thompson 2009a). Although shell membranes are present in most viviparous squamates, embryos develop in close contact with heavily vascularized uterine tissues that provide avenues of transport for oxygen, carbon dioxide, water, and other materials.

Oviparous embryos exchange oxygen and carbon dioxide across the chorioallantoic membrane, a capillary-dense structure that lines most of the inner surface of the eggshell (Stewart \& Thompson 1996, Stewart \& Florian 2000, Blackburn et al. 2003, Stewart et al. 2012). In viviparous species, uterine and chorioallantoic capillaries are closely apposed in the chorioallantoic placenta (Fig. 1A), which likely facilitates the exchange of oxygen and carbon dioxide (Hoffman 1970, Blackburn et al. 1984, 2010, Stewart 1990, 1992, Blackburn 1993a, Blackburn \& Vitt 2002, Murphy et al. 2010b, Blackburn \& Stewart 2011). The epithelia of uterine and chorioallantoic tissues are also attenuated in some viviparous reptiles to bring capillaries closer together and reduce diffusion distances for respiratory gases (Fig. 1A; Adams et al. 2005, Blackburn et al. 2010). In taxa with chorioallantoic placentae that differentiate into a placentome and paraplacentome, the paraplacentome is the region of the chorioallantoic placenta that is primarily responsible for gas exchange (Fig. 1A; Thompson et al. 2004, 2006, Adams et al. 2005, Thompson \& Speake 2006, Wooding et al. 2010).

In viviparous skinks, uterine capillary density increases as embryonic mass and oxygen demand 
increase (Murphy et al. 2010b, Parker et al. 2010), which suggests that embryos might influence the upregulation of uterine angiogenesis (Murphy \& Thompson 2011). Expression of vascular endothelial growth factors (VEGFs) increases in the uterine tissues of $S$. equalis and E. quoyii during pregnancy (Murphy et al. 2010a), so VEGFs are involved in the angiogenic pathway in some species (Murphy \& Thompson 2011). In contrast, VEGF genes are not highly expressed in the pregnant uterus of viviparous $C$. ocellatus skinks. Instead, the angiogenicpromoting gene, endothelial PAS domain protein 1 (EPAS1), is massively upregulated (Brandley et al. 2012). Therefore, similar functions, such as uterine angiogenesis, may have evolved via different genetic pathways in different squamate lineages. Both VEGFs and EPAS1 also regulate uterine angiogenesis in mammals (Sharkey et al. 1993, Song et al. 2008).

In viviparous squamates that exhibit epitheliochorial placentation (i.e. most species; Blackburn \& Vitt 2002, Adams et al. 2005), respiratory gases must cross the uterine and embryonic epithelial tissues to reach apposing capillaries. Respiratory gas transport may differ in Mabuya and Trachylepis, both of which exhibit specializations of embryonic tissues that interact with uterine capillaries (Vieira et al. 2007, Blackburn \& Flemming 2012). As in mammals, fetal hemoglobins of viviparous squamates exhibit higher oxygen affinity than do maternal hemoglobins, which should maximize oxygen diffusion from maternal to fetal circulation (Blackburn 1993a). The mechanism(s) of carbon dioxide excretion from the fetal to maternal circulation are less known. As in mammals, carbonic anhydrases in reptilian erythrocytes convert carbon dioxide to carbonic acid for transport in blood plasma, and re-convert carbonic acid to carbon dioxide in the lung for atmospheric release (Stabenau \& Vietti 2002). A similar mechanism may transport carbon dioxide from the fetal tissues to the chorioallantoic membrane for release to the uterine membrane (Ecay et al. 2010). Alternatively, carbonic acid might not be reconverted to carbon dioxide before transport to the uterine membrane. In the mammalian placentae, carbonic anhydrase is primarily active in the maternal tissues in species with epitheliochorial placentation and in fetal tissues in species with endotheliochorial and hemochorial placentation (Ridderstråle et al. 1997). Thus, because the chorioallantoic placentae of viviparous squamates exhibit epitheliochorial placentation, carbonic anhydrase may be more abundant in the uterine component than in the embryonic component of the placenta.

\section{Water transport}

Eggs of oviparous squamates must uptake water from the environment or resist desiccation (Andrews \& Sexton 1981). Because embryos of viviparous species cannot regulate water balance and gas exchange with the external environment, the evolution of viviparity must include the development of maternal mechanisms to complete these functions in utero (Shine \& Thompson 2006). Viviparous embryos must absorb water while in the uterus, but intrauterine development provides an incubation environment that is water saturated (Shine \& Thompson 2006). Thus, embryonic mechanism(s) for water absorption might change along with the evolutionary transition from oviparity to viviparity. Embryonic water absorption is likely regulated by aquaporins in viviparous species (Wooding et al. 2010). Transcriptomic analysis of a pregnant uterus of the $C$. ocellatus skink revealed significant upregulation of multiple members of the aquaporin gene family, including AQ3, AQ5, and AQ11 (Brandley et al. 2012). In contrast, the primary aquaporins involved in placental water transport in mammals are AQ3, AQ8, and AQ9 (Wang et al. 2001, 2004, Beall et al. 2007). Future transcriptomic analyses of oviparous species will reveal whether the upregulation of aquaporins is specific to viviparous species, but functional studies are also needed to determine the functions of each aquaporin. For example in sheep, placental AQ3 also transports fetal urea to the mother (Johnston et al. 2000), but this role has not been explored in reptiles.

\section{Mechanisms of placental nutrient transport}

In addition to water and respiratory gases, the placentae of viviparous squamates transport inorganic and organic nutrients to varying degrees. Because oviparous squamates utilize the eggshell as a source for $20-80 \%$ of their calcium demand (Packard \& Packard 1988, Shadrix et al. 1994, Stewart et al. 2004), the loss of the eggshell in viviparous species compromises an important component of embryonic nutrition. As a result, viviparous squamates, even those that are primarily lecithotrophic, transport significant quantities of calcium across placentae during development (Thompson et al. 1999b, 1999c, Ramirez-Pinilla 2006, Stewart et al. 2009a, 2009b, Stewart \& Ecay 2010, Ramirez-Pinilla et al. 2011, Stewart 2013). In oviparous species, calcium ATPase is upregulated in the uterus only during eggshell deposition (Thompson et al. 2007), but is upregulated throughout pregnancy in the viviparous skink, Pseudemoia spenceri (Fig. 1A, B and C), presumably to provide calcium to the embryo throughout development (Herbert et al. 2006). In addition, the calcium transporter calbindin- $\mathrm{D}_{28 \mathrm{~K}}$ is expressed in the embryonic membranes of both oviparous and viviparous squamates (Ecay et al. 2004, Fergoso et al. 2012), suggesting that trans-placental calcium transport remains important after the evolution of viviparity (Fig. 1A, B and C). To underscore the importance of calcium placentotrophy in the evolution of squamate viviparity, Stewart (2013) has even suggested that mechanisms of calcium transport, likely co-opted from eggshell deposition, must evolve 
before, or at least concurrently with viviparity for viviparous embryos to receive sufficient calcium to complete embryogenesis. Therefore, structural complexes necessary to accomplish placental calcium transport might provide important foundations for selection to promote greater dependence on placental transport of other nutrients.

Other inorganic nutrients, particularly sodium, potassium, iron, and magnesium, may also be transported across the placentae of viviparous squamates (Fig. 1A, B and C). Placental transport of sodium and potassium has been reported from every viviparous species studied, regardless of reliance on placentotrophy (Hoffman 1970, Thompson 1982, Stewart 1989, Stewart et al. 1990, Thompson et al. 2000, Ramirez-Pinilla 2006, Ramirez-Pinilla et al. 2011). In contrast, the only lecithotrophic species reported to exhibit magnesium transport thus far is Eulamprus tympanum (Thompson et al. 2000, 2001a). Placental transport of iron has only been reported in highly placentotrophic Mabuya skinks (Ramirez-Pinilla 2006, Ramirez-Pinilla et al. 2011), does not occur in lecithotrophic Thamnophis snakes (Hoffman 1970), but has not been investigated in other species (Thompson 1982, Thompson et al. 2000). The mechanisms of inorganic ion transport are largely unknown in viviparous squamates, but in snakes of the genus Thamnophis, sodium may be transported by the yolk-sac placenta to increase osmolarity of the embryo and to facilitate water absorption (Blackburn et al. 2002, Blackburn \& Lorenz 2003). Gene expression profiles of the pregnant uterus of the skink, C. ocellatus, reveal 136 genes in 35 families of solute carrier proteins including transporters of inorganic ions $\left(\mathrm{Ca}^{2+}, \mathrm{Cl}^{-}, \mathrm{CO}_{3}^{2-}, \mathrm{H}^{+}\right.$, $\mathrm{HCO}_{3}^{-}, \mathrm{K}^{+}, \mathrm{Na}^{+}$, and $\left.\mathrm{PO}_{4}^{3}\right)$ and metals $\left(\mathrm{Cu}^{2+}, \mathrm{Fe}^{2 / 3+}{ }^{\prime}\right.$, $\mathrm{Mg}^{2+}$, and $\mathrm{Zn}^{2+}$; Brandley et al. 2012). Thus, nutrient transport is controlled by a large suite of genes, yet we still lack information whether these same genes are also used by other viviparous or oviparous squamates.

Much research has focused on placental provisioning of lipids and amino acids (but not carbohydrates; Blackburn 1994) in viviparous squamates. Radioactive and stable isotope tracer studies have documented transport of amino acids, fatty acids, or both, to the developing offspring in species with (Swain \& Jones 1997, Jones \& Swain 2006, Itonaga et al. 2012) and without (Hoffman 1970, Veith 1974, Thompson 1977, Yaron 1977, Van Dyke \& Beaupre 2012) complex placentation. In contrast, comparisons of mass composition between eggs and newborn offspring suggest that only species with complex placentae exhibit biologically meaningful transport of amino acids and lipids to offspring (Thompson et al. 1999b, 1999c, 2000, 2001b, Flemming \& Branch 2001, Ramirez-Pinilla 2006, Ramirez-Pinilla et al. 2011), while species with simple placentae exhibit net reductions in amino acids and lipids during development (Thompson 1981, Stewart 1989, 1992, Stewart et al. 1990, Blackburn 1994,
Thompson et al. 2000). Paradoxically, species with simple placentae exhibit placental transport of labelled organic nutrient tracers and yet they sustain a net loss of organic nutrients during development. Thus, Blackburn (1994) criticized tracer studies for being unable to distinguish between obligate and incipient placentotrophy, particularly in species that are highly lecithotrophic. Conversely, chemical composition comparisons between eggs and offspring, because they ignore any mass lost as metabolic waste (Blackburn 1994), only measure the net change in the quantity of a given nutrient. As a result, if embryos transport wastes to the mother for excretion, then chemical composition comparisons may underestimate gross placental nutrient transport during development. Respirometric studies clearly show that embryos transport carbon dioxide to mothers during development (Beuchat \& Vleck 1990, Schultz et al. 2008, Van Dyke \& Beaupre 2011). Whether viviparous embryos are also capable of transporting nitrogenous wastes, e.g. urea (Packard et al. 1977), to mothers remains largely untested (Clark \& Sisken 1956). Phylogenetic comparisons of tracer transport among placentotrophic and lecithotrophic species, together with compositional studies that measure metabolic waste production in addition to egg and newborn content, could be useful to determine whether lecithotrophic species with simple placentae are capable of transporting biologically meaningful quantities of organic nutrients to offspring.

Although amino acids and lipids are transported across the placentae of at least some species of viviparous squamates, the mechanisms of transport are poorly understood (Fig. 1A, B and C). In species that exhibit a placentome and paraplacentome, such as the skink genera Mabuya and Pseudemoia, the placentome appears to be a site of histotrophic transport (Fig. 1B; Jerez \& Ramirez-Pinilla 2003, Thompson et al. 2004) or nutrient secretion (Fig. 1B; Thompson et al. 2006). In the skink genus Niveoscincus, $N$. ocellatus exhibits significantly greater reliance on placentotrophy than does N. metallicus (Thompson et al. 1999a, 2001b), but both species exhibit similar placental morphologies that are less structurally complex than those of Pseudemoia sp. (Stewart \& Thompson 2004, 2009a, 2009b). Although they lack a placentome, the highly placentotrophic skinks of the genera Eumecia and Trachylepis appear to transport nutrients across both chorioallantoic and yolk-sac placentae (Flemming \& Branch 2001, Blackburn \& Flemming 2009).

Species in the skink genera Eulamprus, Niveoscincus, and Pseudemoia, as well as the snake genera Thamnophis and Virginia, exhibit hypertrophied uterine epithelial cells, which appear to be secretory, in the yolksac placenta (Fig. 1C; Stewart 1992, Blackburn \& Lorenz 2003, Stewart \& Thompson 2004, Thompson et al. 2006, Stewart \& Thompson 2009a, 2009b). The yolk-sac placenta has been associated with histotrophic nutrient 
transport in Pseudemoia sp. and in some but not all (Thompson et al. 1999a); species of Niveoscincus (Thompson et al. 2001b, 2006, Itonaga et al. 2012). In Pseudemoia sp., the uterine component of the yolk-sac placenta secretes electron-dense vesicles assumed to be rich in lipids (Fig. 1C; Adams et al. 2005), but, which could also be responsible for the transport of amino acids (Itonaga et al. 2012). The epithelium of the yolk-sac placenta of $P$. entrecasteauxii and $P$. spenceri also contains lysosomes that may supply fetal nutrition via histotrophy in the maternal epithelium (Fig. 1C; Biazik et al. 2009). The highly placentotrophic Eumecia sp., Mabuya sp., and Trachylepis sp. also appear to transport nutrients across yolk-sac placentae (Flemming \& Branch 2001, Jerez \& Ramirez-Pinilla 2001, Blackburn \& Flemming 2009). In contrast, the genera Eulamprus, Thamnophis, and Virginia are not placentotrophic, which suggests that uterine epithelial hypertrophy in the yolk-sac placenta is not always associated with organic nutrient transport (Stewart et al. 1990, Thompson et al. 2001a).

Molecular mechanisms of nutrient transport have only been investigated in the placentotrophic skinks $P$. entrecasteauxii, P. spenceri, and C. ocellatus. In Pseudemoia sp., lysosomes and alkaline phosphatase are upregulated in the uterine epithelium of the yolk-sac placenta during pregnancy (Fig. 1C; Biazik et al. 2009). Lysosomes are involved in apocrine secretion, while alkaline phosphatase is usually indicative of glucose and/or lipid transport. Lipoprotein lipase is also heavily expressed in the uterine component of the yolk-sac placenta in pregnant $P$. entrecasteauxii (Fig. 1C; Griffith et al. 2013a). Lipoprotein lipase is responsible for hydrolysis of triglycerides, and in the placenta could function to break down triglycerides into their component fatty acids for repackaging in the vesicles for apocrine secretion to the developing embryo. Furthermore, numerous genes involved in amino acid and lipid packaging and transport are upregulated in the pregnant uterus of $C$. ocellatus (Brandley et al. 2012). These genes included fatty acid-binding proteins $(F A B P 1-5,7)$ that facilitate intracellular transport of fatty acids (Chmurzyńska 2006) and apolipoproteins (APOA, APOE, and APOM), transporters of fatty acids and phospholipids. Moreover, multiple solute carrier protein transporters for glucose, amino acids, and fatty acids are upregulated in the pregnant uterus of $C$. ocellatus. Importantly, many of the same amino acid transporters found in $C$. ocellatus are present in the placentae of eutherian mammals (Verrey et al. 2004).

\section{Regulation of the maternal immune system}

Embryos are allografts of maternal and paternal tissues and are therefore potentially at risk of attack by the maternal immune system. A variety of mechanisms downregulate the immune system in pregnant eutherian mammals to mitigate this risk (see Moffett \& Loke (2006)).
Analyses of immunocompetence and reproduction in viviparous and oviparous squamate reptiles have yielded mixed results. In Agkistrodon piscivorus, a lecithotrophic viviparous snake with a simple placenta, the blood serum of pregnant females has a $\sim 20 \%$ decreased ex-vivo bacterial lysis ability (Graham et al. 2011). Conversely, pregnant females of the lecithotrophic lizard, Z. vivipara, decrease reproductive and physiological performance when immunologically challenged (Meylan et al. 2013), and the placentrophic viviparous skink, C. ocellatus, exhibits reduced immune function during pregnancy (Saad \& El Deeb 1990). On the other hand, the reduced immune function in a gravid oviparous lizard species, Urosaurus ornatus, in the laboratory is related to the amount of food available rather than the reproductive state, per se (French et al. 2007). As previous assessments of immune function in viviparous $A$. piscivorus, C. ocellatus, and $Z$. vivipara did not vary diet in a systematic way, it is unclear whether the demonstrated decreased immune function in pregnant females was due to active downregulation or level of food resources (but see discussion of $C$. ocellatus later).

During pregnancy in the placentrophic skink, C. ocellatus, multiple important innate immune system genes are downregulated, including complement component 3 (C3), the primary activator of the immune complement system (Brandley et al. 2012). In addition, pregnancy in $C$. ocellatus is associated with downregulation of proinflammatory cytokines and upregulation of anti-inflammatory cytokines (inflammation of the uterus is particularly harmful to maintaining pregnancy; Challis et al. 2009). Mammals also regulate $\mathrm{C} 3$ activity in the uterus and placental tissues via the production of complement regulators (Niederkorn 2006, Baek et al. 2007). Thus, the innate immune system is downregulated during pregnancy in C. ocellatus, possibly by a means similar to those of mammals. It is still unclear whether immune downregulation has practical implications for the health of female squamates.

\section{Future research}

Squamate reptiles are an ideal model system for studying the evolution of amniote viviparity because their uterine, embryonic, and placental structures are homologous to those of mammals and other viviparous amniotes. Furthermore, viviparity has evolved over 100 times in squamates, producing multiple independent 'natural experiments' through which to study this transition. Recent advances in next-generation sequencing has been poised to significantly advance our understanding of the oviparity to viviparity transition in squamates (e.g. Brandley et al. (2012)) because we now have the ability to uncover the genetic mechanisms that underlie the morphological and physiological changes associated with viviparity and complex placentation. 
Transcriptomic studies of nonmammalian viviparity and placental development will continue to reveal suites of genes associated with placental functions, including the transport of respiratory gases, water, ions, and, in some species, organic nutrients (Blackburn 1998, Thompson et al. 2000). Furthermore, the specific structural differences on both maternal and uterine components of the chorioallantoic placenta, yolk-sac placenta, placentome, and paraplacentome must be coordinated by embryonic-maternal communication, the mechanism of which remains unknown. In mammals, this communication is facilitated by a number of hormones, including gonadotropins, interleukin $1 \beta$, and insulin-like growth factor (Herrier et al. 2003). There is limited evidence of progesterone production in squamate placentas (Girling \& Jones 2003), and whether squamates use signaling factors similar to those in mammals remains unknown. In addition, there exist multiple examples of immune suppression associated with squamate pregnancy (Saad \& El Deeb 1990, Graham et al. 2011), but it is unclear whether the strength of this suppression is similar across squamates or is instead directly related to increased materno-fetal interaction in highly placentotrophic species. Uterine and embryonic tissues should adhere to one another, both to hold embryos in place and to keep capillary beds aligned to facilitate transport, but the mechanisms of adherence or 'implantation' in most species are unknown (Murphy \& Thompson 2011). Transcriptomic studies are critical to understanding the mechanisms underlying these phenomena, all of which must occur for the transition to viviparity to be successful.

Unfortunately, the small number of sequenced, annotated genomes of squamate species hinders the study of viviparity in the genomics era (the only published squamate genome to date is the oviparous lizard Anolis carolinensis). Increasing the number of sequenced genomes will allow investigation of genome-wide signatures of convergent evolution of viviparity amongst squamates. Also, more genomic information is critical to increase the number of genes identified in sequenced transcriptomes. We also have yet to identify the elements regulating viviparity-associated gene expression; more genomic information will permit evaluation of potential gene expression promoters and the influence of transposable elements on gene expression (e.g. Emera \& Wagner (2012) and Jacques et al. (2013)).

While continuing these gene discovery studies, squamate viviparity researchers must begin to experimentally test the specific functions of genes hypothesized to be important to the evolution of viviparity in reptiles. Unfortunately, a variety of factors, including difficulty of breeding squamates in captivity and the low number of reproductive cycles per year (one to two), make the laboratory production of gene knockout lineages unfeasible in the short-term. Instead, gene functions should be inferred experimentally with techniques using synthetic gene expression inhibitors in concert with transcriptomic sequencing. For example, transcriptomic studies reveal that proteases are highly expressed in the pregnant uterus of placentotrophic squamates (Brandley et al. 2012), and the function of proteases could be assessed by blocking their actions using chemical inhibitors (Barrett et al. 1982). Gene functions may also be inferred using diet manipulations and subsequent effects on nutrient transporter and packaging genes (e.g. Geay et al. (2011) and Hamill et al. (2013)).

All future studies of gene expression and function must be conducted in a comparative phylogenetic framework, including multiple lecithotrophic, placentotrophic, and oviparous lineages, to assess the evolution of the genetic regulators behind viviparity and placental function. For example, what roles do fetal and maternal hormones play in aligning uterine and embryonic tissues for attachment and material exchange? Do placental nutrient transporters evolve de novo in placentotrophic species, or are they co-opted from pre-existing mechanisms in lecithotrophic species? Do the chorioallantoic and yolk sac placentae serve different functions in different lineages of viviparous squamates, and if so, are these functions governed by the expression of the same genes?

Ultimately, these studies will inform perhaps the most basic question in amniote viviparity: is the evolution of viviparity associated with the same suites of genes in both mammals and reptiles? If the $100+$ independent transitions to viviparity in amniotes use different suites of genes to maintain pregnancy, it would be an astounding example of the diversity of ways that natural selection can evolve similar, yet complex phenotypes. If the repeated transition to viviparity is associated with similar suites of genes, implying that there are relatively few ways for viviparity to evolve in amniotes, it would be an equally remarkable example of repeated convergent evolution of both phenotype and genotype. The most recent transcriptomic data available suggest that at least some genes and gene families play similar roles in the uterus and placenta of viviparous mammals and squamates (Brandley et al. 2012). Establishing the diversity (or lack thereof) of genetic mechanisms that underlie the transition to viviparity in squamates will also inform how early therian mammals made this transition. If similar genetic changes occurred during the repeated evolution of viviparity in multiple viviparous squamate lineages and in therian mammals, it will reveal how amniotes use the same elements of the shared ancestral genetic 'toolkit' to make one of the most drastic evolutionary shifts in reproductive morphology and physiology.

\section{Declaration of interest}

The authors declare that there is no conflict of interest that could be perceived as prejudicing the impartiality of the research reported. 


\section{Funding}

This review was supported by an ARC Discovery grant to $\mathrm{M} \mathrm{B}$ Thompson, an ARC DECRA grant to M C Brandley, and a NSF IRFP to J U Van Dyke (\#1064803).

\section{Acknowledgements}

We thank C R Murphy, B Murphy, O Griffith, C Whittington, J McKenna, M Laird, A Seago, and J Herbert for helpful discussions and comments on the manuscript.

\section{References}

Adams SM, Biazik JM, Thompson MB \& Murphy CR 2005 Cytoepitheliochorial placenta of the viviparous lizard Pseudemoia entrecasteauxii: a new placental morphotype. Journal of Morphology 264 264-276. (doi:10.1002/jmor.10314)

Afonso S, Romagnano L \& Babiarz B 1997 The expression and function of cystatin C and cathepsin B and cathepsin L during mouse embryo implantation and placentation. Development 124 3415-3425.

Anderson DT, Manton SM \& Harding JP 1972 Studies on the Onychophora VIII. The relationship between the embryos and the oviduct in the viviparous placental onycophorans Epiperipatus trinadensis Bouvier and Macroperipatus torquatus (kennel) from Trinidad. Philosophical Transactions of the Royal Society of London. Series B, Biological Sciences 264 161-189. (doi:10.1098/rstb.1972.0011)

Andrews RM \& Sexton OJ 1981 Water relations of the eggs of Anolis auratus and Anolis limifrons. Ecology 62 556-562. (doi:10.2307/ 1937721)

Baek K-H, Lee E-J \& Kim Y-S 2007 Recurrent pregnancy loss: the key potential mechanisms. Trends in Molecular Medicine 13 310-317. (doi:10.1016/j.molmed.2007.05.005)

Barrett AJ, Kembhavi AA, Brown MA, Kirschke H, Knight CG, Tama M \& Hanada K 1982 L-Trans-epoxysuccinyl-leucylamido (4-guanidino) butane (E-64) and its analogues as inhibitors of cysteine proteinases including cathepsins B, H, and L. Biochemical Journal 201 189-198.

Beall MH, Wang S, Yang B, Chaudhri N, Amidi F \& Ross MG 2007 Placental and membrane aquaporin water channels: correlation with amniotic fluid volume and composition. Placenta 28 421-428. (doi:10.1016/ j.placenta.2006.06.005)

Bellairs R, Griffiths I \& Bellairs A 1955 Placentation in the adder Vipera berus. Nature 176 657-658. (doi:10.1038/176657b0)

Beuchat CA \& Vleck D 1990 Metabolic consequences of viviparity in a lizard, Sceloporus jarrovi. Physiological Zoology 63 555-570.

Biazik JM, Thompson MB \& Murphy CR 2007 The tight junctional protein occludin is found in the uterine epithelium of squamate reptiles. Journal of Comparative Physiology. B, Biochemical, Systemic, and Environmental Physiology 177 935-943. (doi:10.1007/s00360007-0192-1)

Biazik JM, Thompson MB \& Murphy CR 2008 Claudin-5 is restricted to the tight junction region of uterine epithelial cells in the uterus of pregnant/gravid squamate reptiles. Anatomical Record 291 547-556. (doi:10.1002/ar.20677)

Biazik JM, Thompson MB \& Murphy CR 2009 Lysosomal and alkaline phosphatase activity indicate macromolecule transport across the uterine epithelium in two viviparous skinks with complex placenta. Journal of Experimental Zoology. Part B, Molecular and Developmental Evolution 312 817-826. (doi:10.1002/jez.b.21297)

Biazik JM, Thompson MB \& Murphy CR 2010a Desmosomes in the uterine epithelium of noninvasive skink placentae. Anatomical Record 293 502-512. (doi:10.1002/ar.21093)

Biazik JM, Thompson MB \& Murphy CR 2010b Paracellular and transcellular transport across the squamate uterine epithelium. Herpetological Conservation and Biology 5 257-262.

Blackburn DG 1982 Evolutionary origins of viviparity in the Reptilia. I. Sauria. Amphibia-Reptilia 3 185-205. (doi:10.1163/156853882X00419)
Blackburn DG 1985 Evolutionary origins of viviparity in the Reptilia. II. Serpentes, Amphisbaenia, and Ichthyosauria. Amphibia-Reptilia 5 259-291. (doi:10.1163/156853885X00290)

Blackburn DG 1992 Convergent evolution of viviparity, matrotrophy, and specializations for fetal nutrition in reptiles and other vertebrates. American Zoologist 32 313-321. (doi:10.1093/icb/32.2.313)

Blackburn DG 1993a Chorioallantoic placentation in squamate reptiles: structure, function, development, and evolution. Journal of Experimental Zoology 266 414-430. (doi:10.1002/jez.1402660508)

Blackburn DG 1993b Histology of the late-stage placentae in the matrotrophic skink Chalcides chalcides (Lacertilia; Scincidae). Journal of Morphology 216 179-195. (doi:10.1002/jmor.1052160206)

Blackburn DG 1994 Standardized criteria for the recognition of embryonic nutritional patterns in squamate reptiles. Copeia 1994 925-935. (doi:10. 2307/1446715)

Blackburn DG 1998 Structure, function, and evolution of the oviducts of squamate reptiles, with special reference to viviparity and placentation. Journal of Experimental Zoology 282 560-617. (doi:10.1002/(SICI)1097010X(199811/12)282:4/5<560::AID-JEZ10>3.3.CO;2-A)

Blackburn DG $2000 \mathrm{a}$ Classification of the reproductive patterns of amniotes. Herpetological Monographs 14 371-377. (doi:10.2307/1467051)

Blackburn DG $2000 b$ Reptilian viviparity: past research, future directions, and appropriate models. Comparative Biochemistry and Physiology. Part A, Molecular \& Integrative Physiology 127 391-409. (doi:10.1016/ S1095-6433(00)00272-5)

Blackburn DG 2006 Squamate reptiles as model organisms for the evolution of viviparity. Herpetological Monographs 20 131-146. (doi:10.1655/0733-1347(2007)20[131:SRAMOF]2.0.CO;2)

Blackburn DG \& Flemming AF 2009 Morphology, development, and evolution of fetal membranes and placentation in squamate reptiles. Journal of Experimental Zoology 312B 579-589. (doi:10.1002/jez.b. 21234)

Blackburn DG \& Flemming AF 2012 Invasive implantation and intimate placental associations in a placentotrophic African lizard, Trachylepis ivensi (Scincidae). Journal of Morphology 273 137-159. (doi:10.1002/ jmor.11011)

Blackburn DG \& Lorenz RL 2003 Placentation in garter snakes. III. Transmission EM of the omphalallantoic placenta of Thamnophis radix and T. sirtalis. Journal of Morphology 256 187-204. (doi:10.1002/jmor. 10084)

Blackburn DG \& Stewart JR 2011 Viviparity and placentation in snakes. In Reproductive Biology and Phylogeny of Snakes, pp 119-181. Eds RD Aldridge and DM Sever. Enfield, NH: Science Publishers.

Blackburn DG \& Vitt LJ 2002 Specializations of the chorioallantoic placenta in the Brazilian scincid lizard, Mabuya heathi: a new placental morphotype for reptiles. Journal of Morphology 254 121-131. (doi:10. 1002/jmor.10005)

Blackburn DG, Vitt LJ \& Beauchat CA 1984 Eutherian-like specializations in a viviparous reptile. PNAS $\mathbf{8 1}$ 4860-4863. (doi:10.1073/pnas.81.15. 4860)

Blackburn DG, Stewart JR, Baxter DC \& Hoffman LH 2002 Placentation in garter snakes: scanning EM of the placental membranes of Thamnophis ordinoides and T. sirtalis. Journal of Morphology 252 263-275. (doi:10.1002/jmor.1104)

Blackburn DG, Johnson AR \& Petzold JL 2003 Histology of the extraembryonic membranes of an oviparous snake: towards a reconstruction of basal squamate patterns. Journal of Experimental Zoology. Part A, Comparative Experimental Biology 299 48-58. (doi:10.1002/jez. a.10290)

Blackburn DG, Gavelis GS, Anderson KE, Johnson AR \& Dunlap KD 2010 Placental specializations of the mountain spiny lizard Sceloporus jarrovi. Journal of Morphology 271 1153-1175. (doi:10.1002/jmor.10860)

Brandley MC, Young RL, Warren DL, Thompson MB \& Wagner GP 2012 Uterine gene expression in the live-bearing lizard, Chalcides ocellatus, reveals convergence of squamate reptile and mammalian pregnancy mechanisms. Genome Biology and Evolution 4 394-411. (doi:10.1093/ gbe/evs013)

Burghardt RC, Burghardt JR, Taylor JD II, Reeder AT, Nguen BT, Spencer TE, Bayless KJ \& Johnson GA 2009 Enhanced focal adhesion assembly reflects increased mechanosensation and mechanotransduction at maternal-conceptus interface and uterine wall during ovine pregnancy. Reproduction 137 567-582. (doi:10.1530/REP-08-0304) 
Challis JR, Lockwood CJ, Myatt L, Norman JE, Strauss JF III \& Petraglia F 2009 Inflammation and pregnancy. Reproductive Sciences 16 206-215. (doi:10.1177/1933719108329095)

Chmurzyńska A 2006 The multigene family of fatty acid-binding proteins (FABPs): function, structure and polymorphism. Journal of Applied Genetics 47 39-48. (doi:10.1007/BF03194597)

Clark H \& Sisken BF 1956 Nitrogenous excretion by embryos of the viviparous snake Thamnophis s. sirtalis. Journal of Experimental Biology 33 384-393.

Dey SK, Lim H \& Das SK 2004 Molecular cues to implantation. Endocrine Reviews 25 341-373. (doi:10.1210/er.2003-0020)

Divya P, Chhikara VS, Mahajan S, Datta Gupta S \& Chauhan SS 2002 Differential activity of cathepsin L in human placenta at two different stages of gestation. Placenta 23 59-64. (doi:10.1053/plac.2001.0748)

Ecay TW, Stewart JR \& Blackburn DG 2004 Expression of calbindin- $D_{28 \mathrm{~K}}$ by yolk sac and chorioallantioic membranes of the Corn snake, Elaphe guttata. Journal of Experimental Zoology. Part B, Molecular and Developmental Evolution 302 517-525. (doi:10.1002/jez.a.10290)

Ecay TW, Fregoso SP, Khambaty M \& Stewart JR 2010 Developmental expression of carbonic anhydrase II in the extraembryonic membranes of oviparous and viviparous snakes. FASEB Journal 24 813-814.

Emera D \& Wagner GP 2012 Transformation of a transposon into a derived prolactin promoter with function during human pregnancy. PNAS 109 11246-11251. (doi:10.1073/pnas.1118566109)

Farley RD 1999 Matrotrophic adaptations and early stages of embryogenesis in the desert scorpion Paruroctonus mesaensis (Vaejovidae). Journal of Morphology 237 187-211. (doi:10.1002/(SICI)1097-4687 (199809)237:3 < 187::AID-JMOR1 > 3.0.CO;2-X)

Fergoso SP, Stewart JR \& Ecay TW 2012 Expression of calcium transport proteins in the extraembryonic membranes of a viviparous snake, Virginia striatula. Journal of Experimental Zoology. Part B, Molecular and Developmental Evolution 318 250-256. (doi:10.1002/jez.b.22002)

Flemming AF \& Branch WR 2001 Extraordinary case of matrotrophy in the African skink Eumecia anchietae. Journal of Morphology 247 264-287. (doi:10.1002/1097-4687(200103)247:3 <264::AID-JMOR10 16>3.0.CO;2-P)

French SS, DeNardo DF \& Moore MC 2007 Trade-offs between reproductive and immune systems: facultative responses to resources or obligate responses to reproduction? American Naturalist 170 79-89. (doi:10.1086/518569)

Frick JE 1998 Evidence of matrotrophy in the viviparous holothuroid echinoderm Synaptula hydriformis. Invertebrate Biology 117 169-179. (doi:10.2307/3226968)

Geay F, Ferraresso S, Zambonino-Infante JL, Bargelloni L, Quentel C, Vandeputte M, Kaushik S, Cahu CL \& Mazurais D 2011 Effects of the total replacement of fish-based diet with plant-based diet on the hepatic transcriptome of two European sea bass (Dicentrarchus labrax) halfsibfamilies showing different growth rates with the plant-based diet. $B M C$ Genomics 12 522. (doi:10.1186/1471-2164-12-522)

Ghiara G, Angelini F, Zerani M, Gobbetti A, Cafiero G \& Caputo V 1987 Evolution of viviparity in Scincidae (Reptilia, Lacertilia). Acta Embryologiae et Morphologiae Experimentalis 8 187-201.

Girling JE \& Jones SM 2003 In vitro progesterone production by maternal and embryonic tissues during gestation in the southern snow skink (Niveoscincus microlepidotus). General and Comparative Endocrinology 133 100-108. (doi:10.1016/S0016-6480(03)00147-3)

Graham SP, Earley RL, Guyer C \& Mendonça MT 2011 Innate immune performance and steroid hormone profiles of pregnant versus nonpregnant cottonmouth snakes (Agkistrodon piscivorous). General and Comparative Endocrinology 174 348-353. (doi:10.1016/j.ygcen.2011.09.015)

Griffith OW, Ujvari B, Belov K \& Thompson MB 2013 a Placental lipoprotein lipase (LPL) gene expression in a placentotrophic lizard, Pseudemoia entrecasteauxii. Journal of Experimental Zoology. Part B, Molecular and Developmental Evolution 320 465-470. (doi:10.1002/jez.b.22526)

Griffith OW, Van Dyke JU \& Thompson MB $2013 b$ No implantation in an extrauterine pregnancy of a placentotrophic reptile. Placenta $\mathbf{3 4}$ 510-511. (doi:10.1016/j.placenta.2013.03.002)

Guillette LJ Jr 1993 The evolution of viviparity in lizards. Bioscience 43 742-751. (doi:10.2307/1312318)

Guillette LJ Jr, Spielvogel S \& Moore FL 1981 Luteal development, placentation, and plasma progesterone concentration in the viviparous lizard Sceloporus jarrovi. General and Comparative Endocrinology 43 20-29. (doi:10.1016/0016-6480(81)90027-7)
Hamill RM, Aslan O, Mullen AM, O'Doherty JV, McBryan J, Morris DG \& Sweeney T 2013 Transcriptome analysis of porcine M. semimembranosus divergent in intramuscular fat as a consequence of dietary protein restriction. BMC Genomics 14 453. (doi:10.1186/1471-2164-14-453)

Herbert JF, Lindsay LA, Murphy CR \& Thompson MB 2006 Calcium transport across the uterine epithelium of pregnant lizards. Herpetological Monographs 20 205-211. (doi:10.1655/0733-1347(2007)20[205:CTATUE]2.0.CO;2)

Herrier A, von Rango U \& Beier HM 2003 Embryo-maternal signalling: how the embryo starts talking to its mother to accomplish implantation. Reproductive Biomedicine Online 6 244-256. (doi:10.1016/S14726483(10)61717-8)

Heulin B 1990 Comparative study on eggshell membrane of oviparous and viviparous populations of the lizard Lacerta vivipara. Canadian Journal of Zoology 68 1015-1019. (doi:10.1139/z90-147)

Heulin B, Ghielmi S, Vogrin N, Surget-Groba Y \& Guillaume CP 2002 Variation in eggshell characteristics and in intrauterine egg retention between two oviparous clades of the lizard Lacerta vivipara: insight into the oviparity-viviparity continuum in squamates. Journal of Morphology 252 255-262. (doi:10.1002/jmor.1103)

Heulin B, Stewart JR, Surget-Groba Y, Bellaud P, Jouan F, Lancien G \& Deunff J 2005 Development of the uterine shell glands during preovulatory and early gestation periods in oviparous and viviparous Lacerta vivipara. Journal of Morphology 266 80-93. (doi:10.1002/jmor.10368)

Hoffman LH 1970 Placentation in the garter snake, Thamnophis sirtalis. Journal of Morphology 131 57-88. (doi:10.1002/jmor.1051310105)

Hosie MJ, Adams SM, Thompson MB \& Murphy CR 2003 Viviparous lizard, Eulamprus tympanum, shows changes in uterine surface epithelium during early pregnancy that are similar to the plasma membrane transformation of mammals. Journal of Morphology 258 346-357. (doi:10.1002/jmor.10163)

Hyland RA, Shaw TJ, Png FY \& Murphy CR 1998 Pan-cadherin concentrates apically in uterine epithelial cells during uterine closure in the rat. Acta Histochemica 100 75-81. (doi:10.1016/S0065-1281(98)80007-X)

Itonaga K, Wapstra E \& Jones SM 2012 A novel pattern of placental leucine transfer during mid to late gestation in a highly placentotrophic viviparous lizard. Journal of Experimental Zoology. Part B, Molecular and Developmental Evolution 318 308-315. (doi:10.1002/jez.b.22446)

Jacques P-E, Jeyakani J \& Bourque G 2013 The majority of primate-specific regulatory sequences are derived from transposable elements. PLOS Genetics 9 e1003504. (doi:10.1371/journal.pgen.1003504)

Jerez A \& Ramirez-Pinilla MP 2001 The allantoplacenta of Mabuya mabouya (Sauria, Scincidae). Journal of Morphology 249 132-146. (doi:10.1002/jmor.1045)

Jerez A \& Ramirez-Pinilla MP 2003 Morphogenesis of extraembryonic membranes and placentation in Mabuya mabouya (Squamata, Scincidae). Journal of Morphology 258 158-178. (doi:10.1002/jmor.10138)

Johnston H, Koukoulas I, Jeyaseelan A, Armugam A, Earnest L, Baird R, Dawson N, Ferraro T \& Wintour EM 2000 Ontogeny of aquaporins 1 and 3 in ovine placenta and fetal membranes. Placenta 21 88-99. (doi:10.1053/plac.1999.0445)

Jones SM \& Swain R 2006 Placental transfer of ${ }^{3} \mathrm{H}$-oleic acid in three species of viviparous lizards: a route for supplementation of embryonic fat bodies? Herpetological Monographs 20 186-193. (doi:10.1655/07331347(2007)20[186:PTOHOA]2.0.CO;2)

Jones CJ, Wooding FB, Abd-Elnaeim MM, Leiser R, Dantzer V \& Stoddart RW 2000 Glycolysation in the near-term epitheliochorial placenta of the horse, donkey and camel: a comparative study of interbreeding and non-interbreeding species. Journal of Reproduction and Fertility 118 397-405. (doi:10.1530/reprod/118.2.397)

Lillegraven JA 1979 Reproduction in Mesozoic mammals. In Mesozoic Mammals: The First Two-Thirds of Mammalian History, pp 259-276. Eds JA Lillegraven, Z Kiepan-Jaworowska, and WA Clemens. Berkely, CA: University of California Press.

Mess A \& Carter AM 2007 Evolution of the placenta during the early radiation of placental mammals. Comparative Biochemistry and Physiology. Part A, Molecular \& Integrative Physiology 148 769-779. (doi:10.1016/j.cbpa.2007.01.029)

Meylan S, Richard M, Bauer S, Haussy C \& Miles D 2013 Costs of mounting an immune response during pregnancy in a lizard. Physiological and Biochemical Zoology 86 127-136. (doi:10.1086/668637)

Moffett A \& Loke C 2006 Immunology of placentation in eutherian mammals. Nature Reviews. Immunology 6 584-594. (doi:10.1038/nri1897) 
Murphy BF \& Thompson MB 2011 A review of the evolution of viviparity in squamate reptiles: the past, present and future role of molecular biology and genomics. Journal of Comparative Physiology. B, Biochemical, Systemic, and Environmental Physiology 181 575-594. (doi:10.1007/ s00360-011-0584-0)

Murphy CR, Hosie MJ \& Thompson MB 2000 The plasma membrane transformation facilitates pregnancy in both reptiles and mammals. Comparative Biochemistry and Physiology. Part A, Molecular \& Integrative Physiology 127 433-439. (doi:10.1016/S1095-6433(00)00274-9)

Murphy BF, Belov K \& Thompson MB 2010a Evolution of viviparity and uterine angiogenesis: vascular endothelial growth factor (VEGF) in oviparous and viviparous skinks. Journal of Experimental Zoology. Part B, Molecular and Developmental Evolution 314 145-156.

Murphy BF, Parker SL, Murphy CR \& Thompson MB 2010b Angiogenesis of the uterus and chorioallantois in the eastern water skink Eulamprus quoyii. Journal of Experimental Biology 213 3340-3347. (doi:10.1242/ jeb.046862)

Murphy BF, Parker SL, Murphy CR \& Thompson MB 2011 Placentation in the eastern water skink (Eulamprus quoyii): a placentome-like structure in a lecithotrophic lizard. Journal of Anatomy 218 678-689. (doi:10. 1111/j.1469-7580.2011.01368.x)

Murphy BF, Brandley MC, Murphy CR \& Thompson MB 2012 Evolution of the placentae of Eulamprus quoyii group skinks (Squamata: Scincidae). Journal of Anatomy 220 454-471. (doi:10.1111/j.1469-7580.2012. 01492.x)

Nicholson MDO \& Murphy CR 2005 238. Claudins and occludin in the rat endometrium. Reproduction, Fertility, and Development 17 (Supplement) 94. (doi:10.1071/SRB05Abs238)

Niederkorn JY 2006 See no evil, hear no evil, do no evil: the lessons of immune privilege. Nature Immunology 7 354-359. (doi:10.1038/ni1328)

Packard MJ \& Packard GC 1988 Sources of calcium and phosphorus during embryogenesis in bullsnakes (Pituophis melanoleucus). Journal of Experimental Zoology 246 132-138. (doi:10.1002/jez.1402460205)

Packard GC, Tracy CR \& Roth JJ 1977 The physiological ecology of reptilian eggs and embryos and the evolution of viviparity within the class Reptilia. Biological Reviews 52 71-105. (doi:10.1111/j.1469-185X. 1977.tb01346.x)

Parker SL, Manconi F, Murphy CR \& Thompson MB 2010 Uterine and placental angiogenesis in the Australian skinks, Ctenotus taeniolatus, and Saiphos equalis. Anatomical Record 293 829-838. (doi:10.1002/ar.21052)

Preston AM, Lindsay LA \& Murphy CR 2006 Desmosomes in uterine epithelial cells decrease at the time of implantation: an ultrastructural and morphometric study. Journal of Morphology 267 103-108. (doi:10. 1002/jmor.10390)

Qualls CP 1999 Influence of the evolution of viviparity on eggshell morphology in the lizard Lerista bougainvillii. Journal of Morphology 228 119-125. (doi:10.1002/(SICI)1097-4687(199605)228:2<119::AIDJMOR1 > 3.0.CO;2-0)

Qualls CP \& Shine R 1998 Lerista bougainvillii, a case study for the evolution of viviparity in reptiles. Journal of Evolutionary Biology 11 63-78. (doi:10.1007/s000360050066)

Ramirez-Pinilla MP 2006 Placental transfer of nutrients during gestation in an Andean population of the highly matrotrophic lizard genus Mabuya (Squamata: Scincidae). Herpetological Monographs 20 194-204. (doi:10.1655/0733-1347(2007)20[194:PTONDG]2.0.CO;2)

Ramirez-Pinilla MP, Rueda ED \& Stashenko E 2011 Transplacental nutrient transfer during gestation in the Andean lizard Mabuya sp. (Squamata, Scincidae). Journal of Comparative Physiology. B, Biochemical, Systemic, and Environmental Physiology 181 249-268. (doi:10.1007/ s00360-010-0514-6)

dos Reis M, Inoue J, Haegawa M, Asher RJ, Donoghue PCJ \& Yang Z 2012 Phylogenomic datasets provide both precision and accuracy in estimating the timescale of placental mammal phylogeny. Proceedings. Biological Sciences 279 3491-3500. (doi:10.1098/rspb.2012.0683)

Ridderstråle Y, Persson E, Dantzer V \& Leiser R 1997 Carbonic anhydrase activity in different placenta types: a comparative study of pig, horse, cow, mink, rat, and human. Microscopy Research and Technique 38 115-124. (doi:10.1002/(SICI)1097-0029(19970701/15)38:1/2<115::AI D-JEMT12>3.0.CO;2-S)

Saad A-H \& EI Deeb S 1990 Immunological changes during pregnancy in the viviparous lizard, Chalcides ocellatus. Veterinary Immunology and Immunopathology 25 279-286. (doi:10.1016/0165-2427(90)90051-S)
Salamonsen LA \& Nie G 2002 Proteases at the endometrial-trophoblast interface: their role in implantation. Reviews in Endocrine \& Metabolic Disorders 3 133-143. (doi:10.1023/A:1015407012559)

Samuel CA \& Perry JS 1972 Ultrastructure of pig trophoblast transplanted to an ectopic site in uterine wall. Journal of Anatomy 113 139-149.

Schultz TJ, Webb JK \& Christian KA 2008 The physiological cost of pregnancy in a tropical viviparous snake. Copeia 2003 637-642. (doi:10.1643/CP-06-182)

Shadrix CA, Crotzer DR, McKinney SL \& Stewart JR 1994 Embryonic growth and calcium mobilization in oviposited eggs of the Scincid lizard, Eumeces fasciatus. Copeia 1994 493-498. (doi:10.2307/1446997)

Sharkey AM, Charnock-Jones DS, Boocock CA, Brown KD \& Smith SK 1993 Expression of mRNA for vascular endothelial growth factor in human placenta. Reproduction 99 609-615. (doi:10.1530/jrf.0.0990609)

Shine R \& Thompson MB 2006 Did embryonic responses to incubation conditions drive the evolution of reproductive modes in squamate reptiles? Herpetological Monographs 20 159-171. (doi:10.1655/07331347(2007)20[159:DERTIC]2.0.CO;2)

Smith SA \& Shine R 1997 Intraspecific variation in reproductive mode within the Scincid lizard Saiphos equalis. Australian Journal of Zoology 45 435-445. (doi:10.1071/ZO97023)

Song G, Spencer TE \& Bazer FW 2006 Progesterone and interferon-T regulate cystatin C in the endometrium. Endocrinology 147 3478-3483. (doi:10.1210/en.2006-0122)

Song G, Bazer FW \& Spencer TE 2007 Differential expression of cathepsins and cystatin C in ovine uteroplacental tissues. Placenta 28 1091-1098. (doi:10.1016/j.placenta.2007.04.004)

Song G, Kim J, Bazer FW \& Spencer TE 2008 Progesterone and interferon $\tau$ regulate hypoxia-inducible factors in the endometrium of the ovine uterus. Endocrinology 149 1926-1934. (doi:10.1210/en.2007-1530)

Song G, Bailey DW, Dunlap KA, Burghardt RC, Spencer TE, Bazer FW \& Johnson GA 2010 Cathepsin B, cathepsin L, and cystatin C in the porcine uterus and placenta: potential roles in endometrial/placental remodeling and in fluid-phase transport of proteins secreted by uterine epithelia across placental areolae. Biology of Reproduction 82 854-864. (doi:10. 1095/biolreprod.109.080929)

Stabenau EK \& Vietti KR 2002 Pulmonary carbonic anhydrase in the Garter snake, Thamnophis sirtalis. Physiological and Biochemical Zoology 75 83-89. (doi:10.1086/339218)

Stewart JR 1989 Facultative placentotrophy and the evolution of squamate placentation: quality of eggs and neonates in Virginia striatula. American Naturalist 133 111-137. (doi:10.1086/284904)

Stewart JR 1990 Development of the extraembryonic membranes and histology of the placentae in Virginia striatula (Squamata: Serpentes). Journal of Morphology 205 33-43. (doi:10.1002/jmor. 1052050105)

Stewart JR 1992 Placental structure and nutritional provision to embryos in predominantly lecithotrophic viviparous reptiles. American Zoologist 32 303-312. (doi:10.1093/icb/32.2.303)

Stewart JR 1993 Yolk sac placentation in reptiles: structural innivation in a fundamental vertebrate nutritional system. Journal of Experimental Zoology 266 431-449. (doi:10.1002/jez.1402660509)

Stewart JR 2013 Fetal nutrition in lecithotrophic squamate reptiles: toward a comprehensive model for evolution of viviparity and placentation. Journal of Morphology 274 824-843. (doi:10.1002/jmor.20141)

Stewart JR \& Blackburn DG 1988 Reptilian placentation: structural diversity and terminology. Copeia 1988 839-852. (doi:10.2307/1445706)

Stewart JR \& Ecay TW 2010 Patterns of maternal provision and embryonic mobilization of calcium in oviparous and viviparous squamate reptiles. Herpetological Conservation and Biology 5 341-359.

Stewart JR \& Florian JD Jr 2000 Ontogeny of the extraembryonic membranes of the oviparous lizard, Eumeces fasciatus (Squamata: Scincidae). Journal of Morphology 244 81-107. (doi:10.1002/ (SICl)1097-4687(200005)244:2<81::AID-JMOR1 > 3.0.CO;2-D)

Stewart JR \& Thompson MB 1996 Evolution of reptilian placentation: development of extraembryonic membranes of the Australian scincid lizards, Bassiana duperreyi (Oviparous) and Pseudemoia entrecasteauxii (Viviparous). Journal of Morphology 227 349-370. (doi:10.1002/ (SICI)1097-4687(199603)227:3 < 349::AID-JMOR6>3.0.CO;2-0)

Stewart JR \& Thompson MB 2004 Placental ontogeny of the Tasmanian scincid lizard, Niveoscincus ocellatus (Reptilia: Squamata). Journal of Morphology 259 214-237. (doi:10.1002/jmor.10179) 
Stewart JR \& Thompson MB 2009a Parallel evolution of placentation in Australian Scincid lizards. Journal of Experimental Zoology. Part B, Molecular and Developmental Evolution 312 590-602. (doi:10.1002/jez.b.21245)

Stewart JR \& Thompson MB $2009 b$ Placental ontogeny in Tasmanian snow skinks (genus Niveoscincus) (Lacertilia: Scincidae). Journal of Morphology 270 485-516. (doi:10.1002/jmor.10704)

Stewart JR, Blackburn DG, Baxter DC \& Hoffman LH 1990 Nutritional provision to embryos in a predominantly lecithotrophic placental reptile, Thamnophis ordinoides (Squamata: Serpentes). Physiological Zoology $63722-734$.

Stewart JR, Ecay TW \& Blackburn DG 2004 Sources and timing of calcium mobilization during embryonic development of the corn snake, Pantherophis guttatus. Comparative Biochemistry and Physiology. Part A, Molecular \& Integrative Physiology 139 335-341. (doi:10.1016/ j.cbpb.2004.09.016)

Stewart JR, Ecay TW, Garland CP, Fregoso SP, Price EK, Herbert JF \& Thompson MB 2009a Maternal provision and embryonic uptake of calcium in an oviparous and a placentotrophic viviparous Australian lizard (Lacertilia: Scincidae). Comparative Biochemistry and Physiology. Part A, Molecular \& Integrative Physiology 153 202-208. (doi:10.1016/j. cbpa.2009.02.014)

Stewart JR, Ecay TW \& Heulin B 2009b Calcium provision to oviparous and viviparous embryos of the reproductively bimodal lizard Lacerta (Zootoca) vivipara. Journal of Experimental Biology 212 2520-2524. (doi:10.1242/jeb.030643)

Stewart JR, Russell KJ \& Thompson MB 2012 Development of yolk sac and chorioallantoic membranes in the Lord Howe Island Skink, Oligosoma lichenigerum. Journal of Morphology 273 1163-1184. (doi:10.1002/ jmor.20052)

Swain R \& Jones SM 1997 Maternal-fetal transfer of ${ }^{3} \mathrm{H}$-labelled leucine in the viviparous lizard Niveoscincus metallicus (Scincidae: Lygosominae). Journal of Experimental Zoology 277 139-145. (doi:10.1002/(SICl)1097010X(19970201)277:2 < 139::AID-JEZ5 > 3.0.CO;2-Q)

Thompson J 1977 The transfer of amino acids across the placenta of a viviparous lizard, Sphenomorphus quoyii. Theriogenology 8158. (doi:10.1016/0093-691X(77)90120-0)

Thompson J 1981 A study of the sources of nutrients for embryonic development in a viviparous lizard, Sphenomorphus quoyii. Comparative Biochemistry and Physiology. Part A, Physiology 70 509-518. (doi:10.1016/0300-9629(81)92562-7)

Thompson J 1982 Uptake of inorganic ions from the maternal circulation during development of the embryo of a viviparous lizard Sphenomorphus quoyii. Comparative Biochemistry and Physiology. Part A, Physiology 71 107-112. (doi:10.1016/0300-9629(82)90374-7)

Thompson MB \& Speake BK 2006 A review of the evolution of viviparity in lizards: structure, function and physiology of the placenta. Journal of Comparative Physiology. B, Biochemical, Systemic, and Environmental Physiology 176 179-189. (doi:10.1007/s00360-005-0048-5)

Thompson MB, Speake BK, Stewart JR, Russell KJ, McCartney RJ \& Surai PF 1999a Placental nutrition in the viviparous lizard Niveoscincus metallicus: the influence of placental type. Journal of Experimental Biology 202 2985-2992.

Thompson MB, Stewart JR, Speake BK, Russell KJ \& McCartney RJ $1999 b$ Placental transfer of nutrients during gestation in the viviparous lizard, Pseudemoia spenceri. Journal of Comparative Physiology. B, Biochemical, Systemic, and Environmental Physiology 169 319-328. (doi:10.1007/s003600050227)

Thompson MB, Stewart JR, Speake BK, Russell KJ, McCartney RJ \& Surai PF 1999C Placental nutrition in a viviparous lizard (Pseudemoia pagenstecheri) with a complex placenta. Journal of Zoology 248 295-305. (doi:10.1111/j.1469-7998.1999.tb01030.x)

Thompson MB, Stewart JR \& Speake BK 2000 Comparison of nutrient transport across the placenta of lizards differing in placental complexity. Comparative Biochemistry and Physiology. Part A, Molecular \& Integrative Physiology 127 469-479. (doi:10.1016/S1095-6433(00) 00277-4)

Thompson MB, Speake BK, Russell KJ \& McCartney RJ 2001 a Nutrient uptake by embryos of the Australian viviparous lizard Eulamprus tympanum. Physiological and Biochemical Zoology 74 560-567. (doi:10.1086/322166)
Thompson MB, Speake BK, Stewart JR, Russell KJ \& McCartney RJ $2001 b$ Placental nutrition in the Tasmanian skink, Niveoscincus ocellatus. Journal of Comparative Physiology. B, Biochemical, Systemic, and Environmental Physiology 171 155-160. (doi:10.1007/s003600000166)

Thompson MB, Adams SM, Herbert JF, Biazik JM \& Murphy CR 2004 Placental function in lizards. International Congress Series/Excerpta Medica 1275 218-225. (doi:10.1016/j.ics.2004.08.055)

Thompson MB, Biazik JB, Lui S, Adams SM \& Murphy CR 2006 Morphological and functional changes to the uterus of lizards with different placental complexities. Herpetological Monographs 20 178-185. (doi:10.1655/0733-1347(2007)20[178:MAFCTT]2.0.CO;2)

Thompson MB, Lindsay LA, Herbert JF \& Murphy CR 2007 Calcium ATPase expression in the oviducts of the skink, Lampropholis guichenoti. Comparative Biochemistry and Physiology. Part A, Molecular \& Integrative Physiology 147 1090-1094. (doi:10.1016/j.cbpa.2007.03.029)

Van Dyke JU \& Beaupre SJ 2011 Bioenergetic components of reproductive effort in viviparous snakes: costs of vitellogenesis exceed costs of pregnancy. Comparative Biochemistry and Physiology. Part A, Molecular \& Integrative Physiology 160 504-515. (doi:10.1016/j.cbpa. 2011.08.011)

Van Dyke JU \& Beaupre SJ 2012 Stable isotope tracer reveals that viviparous snakes transport amino acids to offspring during gestation. Journal of Experimental Biology 215 760-765. (doi:10.1242/jeb.058644)

Varanou A, Withington SL, Lakasing L, Williamson C, Burton GJ \& Hemberger M 2006 The importance of cysteine cathepsin proteases for placental development. Journal of Molecular Medicine 84 305-317. (doi:10.1007/s00109-005-0032-2)

Veith WJ 1974 Reproductive biology of Chamaeleo pumilus pumilus with special reference to the role of the corpus luteum and progesterone. Zoologica Africana 9 161-183.

Verrey F, Closs El, Wagner CA, Palacin M, Endou H \& Kanai Y 2004 CATs and HATs: the SLC7 family of amino acid transporters. Pflügers Archiv: European Journal of Physiology 447 532-542. (doi:10.1007/s00424003-1086-z)

Vieira S, de Perez G \& Ramirez-Pinilla MP 2007 Invasive cells in the placentome of Andean populations of Mabuya: an endotheliochorial contribution to the placenta. Anatomical Record 290 1508-1518. (doi:10.1002/ar.20609)

Wang S, Kallichanda N, Song W, Ramirez BA \& Ross MG 2001 Expression of aquaporin-8 in human placenta and chorioamniotic membranes: evidence of molecular mechanism for intramembranous amniotic fluid resorption. American Journal of Obstetrics and Gynecology $\mathbf{1 8 5}$ 1226-1231. (doi:10.1067/mob.2001.117971)

Wang S, Chen J, Beall M, Zhou W \& Ross MG 2004 Expression of aquaporin 9 in human chorioamniotic membranes and placenta. American Journal of Obstetrics and Gynecology 191 2160-2167. (doi:10.1016/ j.ajog.2004.05.089)

Weekes HC 1935 A review of placentation among reptiles with particular regard to the function and evolution of the placenta. Proceedings of the Zoological Society 2 625-645. (doi:10.1111/j.1096-3642.1935.tb01686.x)

Wooding FB, Ramirez-Pinilla MP \& Forhead AS 2010 Functional studies of the placenta of the lizard Mabuya sp. (Scincidae) using immunocytochemistry. Placenta 31 675-685. (doi:10.1016/j.placenta.2010.04.001)

Wourms JP 1977 Reproduction and development in chondrichthyan fishes. American Zoologist 17 379-410. (doi:10.1093/icb/17.2.379)

Wourms JP 1981 Viviparity: the maternal-fetal relationship in fishes. American Zoologist 21 473-515. (doi:10.1093/icb/21.2.473)

Wu Q, Thompson MB \& Murphy CR 2011 Changing distribution of cadherins during gestation in the uterine epithelium of lizards. Journal of Experimental Zoology. Part B, Molecular and Developmental Evolution 316 440-450. (doi:10.1002/jez.b.21419)

Yaron Z 1977 Embryo-maternal interrelations in the lizard Xantusia vigilis. In Reproduction and Evolution, pp 527-603. Eds JH Calaby and $\mathrm{CH}$ Tyndale-Briscoe. Canberra, ACT: Australian Academy of Science.

Received 15 July 2013

First decision 9 September 2013

Revised manuscript received 10 October 2013

Accepted 14 October 2013 